\title{
FAKTOR-FAKTOR YANG BERHUBUNGAN DENGAN KEINGINAN PERPINDAHAN FASILITAS KESEHATAN TINGKAT PERTAMA PADA PESERTA JKN MANDIRI DI KOTA DENPASAR TAHUN 2017
}

\author{
Iwan Abdi Suandana*, Pande Putu Januraga, Putu Ayu Indrayathi \\ Program Studi Kesehatan Masyarakat Fakultas Kedokteran Universitas Udayana \\ *email: iwanabdi65@yahoo.co.id
}

\begin{abstract}
ABSTRAK
Keinginan pindah fasilitas kesehatan tingkat pertama merupakan salah satu bentuk ketidakpuasan pasien serta akan berdampak pada loyalitas pasien dalam memanfaatkan pelayanan kesehatan. Pada tahun 2016, terjadi peningkatan yang signifikan pada peserta JKN Mandiri di Kota Denpasar yang melakukan perpindahan FKTP yaitu di bulan Juni sebanyak 453 orang dan menjadi 504 orang pada bulan November 2016. Berdasarkan hasil wawancara dengan pihak BPJS Kesehatan Cabang Denpasar didapatkan data mengenai keluhan peserta JKN di FKTP di Kota Denpasar meliputi pelayanan yang kurang ramah, kurang informatif, antrian panjang, penolakan pasien luar wilayah dan pasien tidak terlayani karena berobat di luar jam kerja FKTP. Penelitian ini bertujuan untuk mengetahui faktor-faktor yang berhubungan dengan keinginan pindah FKTP pada peserta JKN Mandiri di Kota Denpasar. Desain penelitian ini menggunakan analitik crossectional dengan jumlah sampel 108 orang. Teknik pengambilan sampel dilakukan dengan cara consecutive sampling di beberapa FKTP yang bekerjasama dengan BPJS Kesehatan di Kota Denpasar. Pengumpulan data dilakukan dengan kuesioner dan dianalisis dengan analisis univariat, bivariat (chi-square) dan multivariat (regresi logistik) Berdasarkan hasil mutivariat didapatkan hasil terdapat hubungan antara ketersediaan fasilitas ( $\mathrm{p}=0,005,95 \% \mathrm{CI}=2,05-56,57)$, waktu tunggu $(\mathrm{p}=0,000,95 \% \mathrm{CI}=5,98-233,68)$, jarak ( $\mathrm{p}=0,000,95 \% \mathrm{CI}=3,66-51,92)$, pindah domisili $(\mathrm{p}=0,022,95 \% \mathrm{CI}=1,34-43,01)$ dan pelayanan dokter $(\mathrm{p}=0,005,95 \% \mathrm{CI}=2,02-55,32)$ dengan keinginan pindah FKTP, sedangkan waktu pelayanan tidak mempunyai hubungan dengan keinginan pindah FKTP ( $\mathrm{p}=0,138,95 \% \mathrm{CI}=0,50-147,25)$. Adapun faktor yang paling dominan terhadap keinginan pindah FKTP yaitu waktu tunggu ( $p=0,000$ dan Adjust OR=37,38) Bagi pihak FKTP sebaiknya dapat meningkatkan kualitas mutu pelayanan yang diberikan pada peserta JKN serta bagi BPJS Kesehatan dapat meningkatkan penilaian terhadap FKTP yang bekerjasama dengannya dalam hal kredensialing dan rekredensialing FKTP.
\end{abstract}

Kata Kunci: Perpindahan, FKTP, JKN

\begin{abstract}
The desire to move first-level health facilities is one form of patient dissatisfaction and will have an impact on patient loyalty in utilizing health services. In 2016, there was a significant increase in JKN Mandiri participants in Denpasar City who moved FKTP in June as many as 453 people and became 504 people in November 2016. Based on interviews with BPJS Health Denpasar Branch data obtained about JKN participants' complaints in FKTP in Denpasar City includes services that are not friendly, less informative, long queues, rejection of patients outside the region and patients not served because of treatment outside FKTP working hours. This study aims to determine the factors associated with the desire to move FKTP on JKN Mandiri participants in Denpasar City. The design of this study used cross-sectional analytics with a sample of 108 people. The sampling technique was done by consecutive sampling in several FKTP in collaboration with BPJS Health in Denpasar City. Data collection was carried out by questionnaire and analyzed by univariate, bivariate (chi-square) and multivariate (logistic regression) analysis. Based on the results of the mutivariat, there was a correlation between the availability of facilities $(\mathrm{p}=0.005,95 \% \mathrm{CI}=2.05-56.57)$, waiting time $(\mathrm{p}=0,000,95 \% \mathrm{CI}=5.98-233.68)$, distance $(\mathrm{p}$ $=0,000,95 \% \mathrm{CI}=3.66-51.92)$, moving domicile $(\mathrm{p}=0.022,95 \% \mathrm{CI}=1.34-43.01)$ and doctor's service $(\mathrm{p}=0.005,95 \%$ $\mathrm{CI}=2.02-55.32)$ with the desire to move FKTP, while the service time has no relationship with the desire to move FKTP ( $p=0.138,95 \%$ CI = 0.50-147.25). The most dominant factor for the desire to move FKTP is the waiting time $(\mathrm{p}=0,000$ and Adjust OR = 37.38) For the FKTP it should be able to improve the quality of service provided to JKN participants and for BPJS Health can improve the assessment of FKTP in collaboration with in terms of FKTP credentialing and recruitment.
\end{abstract}

Keywords: Displacement, FKTP, JKN 


\section{PENDAHULUAN}

Fasilitas Kesehatan Tingkat Pertama (FKTP) merupakan fasilitas yang menyelenggarakan pelayanan kesehatan primer untuk peserta JKN yang meliputi Puskesmas, Praktik Dokter, Praktik Dokter Gigi, Klinik Pratama, dan Rumah Sakit Kelas D Pratama. Fasilitas Kesehatan Tingkat Pertama (FKTP) ini nantinya digunakan oleh peserta JKN untuk melakukan pengobatan pertama kali (BPJS Kesehatan, 2014). BPJS Kesehatan juga memfasilitasi untuk peserta JKN yang ingin melakukan perpindahan FKTP, dengan syarat minimal harus berjalan 3 bulan sejak terdaftar di faskes sebelumnya. Dengan adanya aturan tersebut, pada kenyataannya banyak peserta JKN yang ingin melakukan perpindahan FKTP. Berdasarkan data BPJS Kesehatan Cabang Denpasar (2016) peserta yang melakukan perpindahan FKTP lebih didominasi oleh peserta JKN Mandiri. Menurut data dari BPJS Kesehatan Cabang Denpasar terjadi peningkatan yang signifikan peserta JKN Mandiri di Denpasar yang melakukan perpindahan FKTP yaitu bulan Juni sebanyak 453 orang dan menjadi 504 orang pada bulan November 2016. Banyaknya perpindahan FKTP yang dilakukan oleh peserta JKN ini mengindikasikan masih kurangnya kualitas mutu pelayanan yang diberikan yang berdampak pada kepuasan pasien JKN. Berdasarkan hasil wawancara dengan pihak BPJS Kesehatan Cabang Denpasar didapatkan data mengenai keluhan peserta JKN di FKTP di Kota Denpasar meliputi pelayanan yang kurang ramah, kurang informatif, antrian panjang, penolakan pasien luar wilayah dan pasien tidak terlayani karena berobat di luar jam kerja
FKTP. Hal ini merupakan indikasi adanya permasalahan dalam kepuasan pasien JKN (Widiastuti, 2015). Penelitian Widiastuti (2015) juga menyatakan bahwa terdapat hubungan signifikan pada jenis FKTP yang dipilih dengan kepuasan pasien JKN. Ketidakpuasan pasien atau masyarakat dalam menggunakan layanan kesehatan cenderung menyebabkan ketidakpatuhan pasien dalam kegiatan pengobatan, tidak menuruti nasehat dan pindah ke faskes lainnya (Pohan, 2006). Berdasarkan studi pendahuluan dengan melakukan wawancara kepada 50 peserta JKN yang melakukan perpindahan FKTP di BPJS Kesehatan Cabang Denpasar ada beberapa faktor yang mempengaruhi perpindahan FKTP antara lain: jarak ke FKTP, pelayanan dokter di FKTP, ketersediaan fasilitas di FKTP, waktu pelayanan FKTP di FKTP, waktu tunggu untuk mendapatkan pelayanan di FKTP, serta alasan pindah domisili peserta JKN. Adapun tujuan penelitian ini adalah untuk mengetahui faktor-faktor yang berhubungan dengan keinginan pindah FKTP pada peserta JKN Mandiri di Kota Denpasar.

\section{METODE}

Design Penelitian ini adalah penelitian analitik kuantitatif dengan rancangan crossectional. Penelitian ini dilakukan selama 3 bulan (Maret-Mei 2017) di Kota Denpasar. Populasi target dalam penelitian ini adalah peserta JKN Mandiri dan populasi terjangkau yaitu peserta JKN Mandiri di Kota Denpasar selama kurun waktu periode penelitian. Sedangkan sampel harus memenuhi kriteria inklusi yaitu 1) Peserta yang tercatat sebagai peserta JKN Mandiri di FKTP BPJS Kesehatan Kota Denpasar dan minimal telah 1 kali berkunjung 2) Peserta 
JKN Mandiri minimal berusia 17 tahun dengan asumsi dapat memberikan informasi yang berkaitan dengan penelitian dan 3) Mampu berkomunikasi dan bersedia menjadi responden. Teknik pengambilan sampel dalam penelitian ini menggunakan Non-Probability Sampling dengan jenis teknik consecutive sampling. Pada saat pengumpulan

\section{HASIL}

sampel, peneliti menunggu peserta yang datang ke beberapa FKTP di Denpasar. FKTP yang dipilih sejumlah 8 FKTP yang bekerjasama dengan BPJS Kesehatan. Adapun jumlah sampel dalam penelitian ini yaitu 108 sampel.

Tabel 1. Gambaran karakteristik responden berdasarkan sosiodemografi (umur, pendidikan, dan pekerjaan)

\begin{tabular}{lcc}
\hline Umur & Frekuensi & Persentase \\
\hline$(>37$ thn $)$ & 48 & $44,44 \%$ \\
$(17-37$ thn $)$ & 60 & $55,56 \%$ \\
Pendidikan & & \\
Rendah & 21 & $19,44 \%$ \\
Tinggi & 87 & $80,56 \%$ \\
Pekerjaan & & \\
Bekerja & 66 & $60,61 \%$ \\
Tdk bekerja & 42 & $39,39 \%$ \\
Total & 108 & $100 \%$ \\
\hline
\end{tabular}

Berdasarkan tabel 1, dapat dilihat responden yang berpendidikan rendah yaitu nilai rata-rata umur yaitu 37 tahun dan tamatan (< SMA) sebanyak 21 orang umur terendah yaitu umur 17 tahun. Jadi (19,44\%) dan yang berpendidikan tinggi dapat dilihat responden dalam penelitian ini yaitu tamatan ( $\geq$ SMA) sebanyak 87 orang yang berumur $>37$ tahun sebanyak 48 orang $\quad(80,56 \%)$. Sedangkan dari segi pekerjaan (44,44\%) dan yang berumur 17-37 tahun dapat diketahui responden dalam penelitian sebanyak 60 orang (55,56\%). Sedangkan dari ini yang tidak bekerja sebanyak 42 orang segi pendidikan, dari seluruh responden (39,39\%) dan yang bekerja sebanyak 66 yang ditemui saat pengumpulan data, orang $(60,61 \%)$

Tabel 2. Distribusi Keinginan Perpindahan Fasilitas Kesehatan Tingkat Pertama berdasarkan Karakteristik Responden (Umur, Pendidikan, dan Pekerjaan)

\begin{tabular}{llllll}
\hline Variabel & \multicolumn{5}{c}{ Keinginan Pindah } \\
\cline { 2 - 6 } Umur & $\begin{array}{l}\text { Ingin } \\
\text { pindah }\end{array}$ & $\begin{array}{l}\text { Persentase } \\
(\%)\end{array}$ & $\begin{array}{l}\text { Tidak ingin } \\
\text { pindah }\end{array}$ & $\begin{array}{l}\text { Persentase } \\
(\%)\end{array}$ & Total \\
$\quad>37$ tahun & 15 & $31,25 \%$ & 33 & $68,75 \%$ & $48(100 \%)$ \\
17-37 tahun & 25 & $41,67 \%$ & 35 & $58,33 \%$ & $60(100 \%)$
\end{tabular}

Pendidikan 


$\begin{array}{llllll}\text { Rendah } & 7 & 33,33 \% & 14 & 66,67 \% & 21(100 \%) \\ \text { Tinggi } & 33 & 37,93 \% & 54 & 62,07 \% & 87(100 \%)\end{array}$

Pekerjaan

\begin{tabular}{llllll} 
Tidak bekerja & 14 & $33,33 \%$ & 28 & $66,67 \%$ & $42(100 \%)$ \\
Bekerja & 26 & $39,39 \%$ & 40 & $60,61 \%$ & $66(100 \%)$ \\
\hline Total & 40 & $37,04 \%$ & 68 & $62,96 \%$ & $108(100 \%)$
\end{tabular}

Berdasarkan tabel 2, responden yang terakhirnya tinggi ( $\geq$ SMA) yaitu sebanyak lebih banyak ingin pindah FKTP lebih (37,93\%) dan yang telah bekerja sebanyak didominasi oleh responden yang berumur $(39,39)$ 17-37 tahun sebanyak $(41,67 \%)$, pendidikan

Tabel 3. Hubungan antara Ketersediaan Fasilitas, Pelayanan Dokter, Waktu Pelayanan, Waktu Tunggu, Jarak dan Pindah Domisili dengan Keinginan Pindah FKTP pada peserta JKN Mandiri di Kota Denpasar

\begin{tabular}{|c|c|c|c|c|c|}
\hline \multirow[b]{2}{*}{ Variabel } & \multicolumn{2}{|c|}{ Keinginan pindah FKTP } & \multirow{2}{*}{$\begin{array}{c}\text { Crude } \\
\text { OR }\end{array}$} & \multirow{2}{*}{$\begin{array}{c}\text { Nilai } 95 \% \\
\text { CI }\end{array}$} & \multirow[t]{2}{*}{ Nilai $p$} \\
\hline & $\begin{array}{l}\text { Ingin Pindah } \\
(\%)\end{array}$ & $\begin{array}{l}\text { Tidak Ingin } \\
\text { Pindah (\%) }\end{array}$ & & & \\
\hline \multicolumn{6}{|c|}{ Ketersediaan Fasilitas } \\
\hline Tidak lengkap & $8(66,67 \%)$ & $4(33,33 \%)$ & 4 & $1,96-19,2$ & 0,0242 \\
\hline Lengkap & $32(33,33 \%)$ & $64(66,67 \%$ & & & \\
\hline \multicolumn{6}{|l|}{ Pelayanan dokter } \\
\hline Buruk & $10(71,43 \%)$ & $4(28,57 \%)$ & 5,33 & $1,37-24,8$ & 0,0043 \\
\hline Baik & $30(31,91 \%)$ & $64(68,09 \%)$ & & & \\
\hline \multicolumn{6}{|l|}{ Waktu Pelayanan } \\
\hline Tidak sesuai & $5(83,33 \%)$ & $1(16,67 \%)$ & 2,42 & $1,55-13,78$ & 0,0157 \\
\hline Sesuai & $35(34,31 \%)$ & $67(65,69 \%)$ & & & \\
\hline \multicolumn{6}{|l|}{ Waktu tunggu } \\
\hline Lama & $13(86,67 \%)$ & $2(13,33 \%)$ & 15,88 & $3,1-150,2$ & 0,0000 \\
\hline Tidak lama & $27(29,03 \%)$ & $66(70,97 \%)$ & & & \\
\hline \multicolumn{6}{|l|}{ Jarak } \\
\hline Jauh & $20(74,07 \%)$ & $7(25,93 \%)$ & 8,71 & $2,93-27,5$ & 0,0000 \\
\hline Dekat & $20(24,69 \%)$ & $61(89,71 \%)$ & & & \\
\hline \multicolumn{6}{|l|}{ Pindah Domisili } \\
\hline Pernah & $11(78,57 \%)$ & $3(21,43 \%)$ & 8,21 & $1,93-48,2$ & 0,0006 \\
\hline Tidak pernah & $29(30,85 \%)$ & $65(69,15 \%)$ & & & \\
\hline
\end{tabular}


Berdasarkan tabel 3, hasil uji bivariat dengan menggunakan chisquare dipeloreh 6 variabel yang memiliki hubungan yang signifikan $(\mathrm{p}<0,05)$ terhadap keinginan perpindahan
FKTP yaitu ketersediaan fasilitas, pelayanan dokter, waktu pelayanan, waktu tunggu, jarak, dan pindah domisili

Tabel 4. Hasil Model Akhir Uji Regresi Logistik dari hubungan Ketersediaan fasilitas, pelayanan dokter, waktu tunggu, jarak, serta pindah domisili dengan keinginan pindah FKTP pada peserta JKN Mandiri di Kota Denpasar

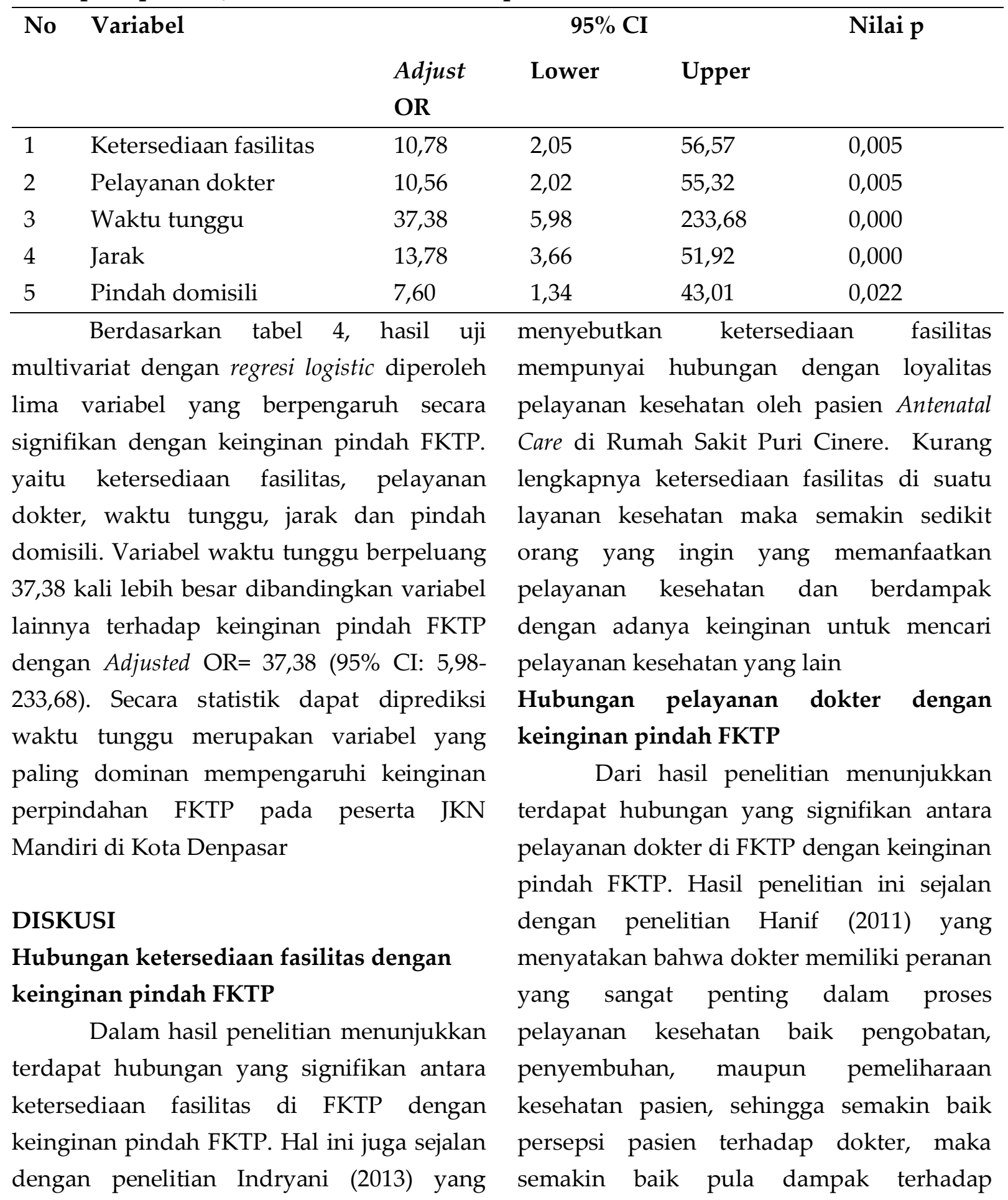


kesehatan pasien dan utilisasi pelayanan kesehatan. Dimana semakin baik pelayanan dokter maka kemungkinan pasien akan kembali lagi berobat di dokter tersebut, dan semakin kurang baik pelayanan dokter tersebut maka kemungkinan pasien ingin mencari dokter yang baru.

Hubungan waktu pelayanan dengan keinginan pindah FKTP

Berdasarkan hasil penelitian menunjukkan tidak terdapat hubungan antara waktu pelayanan di FKTP dengan keinginan pindah FKTP. Selanjutnya penelitian yang dilakukan oleh Dinik (2008) juga menunjukkan bahwa terdapat hubungan antara kesesuaian jadwal pelayanan di Puskesmas Bringin Kabupaten Semarang dengan tingkat kepuasan pasien dimana semakin sesuai jadwal pelayanan maka semakin tinggi tingkat kepuasaan pasien. Tingkat kepuasan pasien ini akan menimbulkan loyalitas pasien dalam memanfaatkan pelayanan kesehatan, dimana pasien akan cenderung memanfaatkan kembali pelayanan kesehatan jika jadwal pelayanan yang dijanjikan sesuai dengan waktu kerjanya dan jika jadwal pelayanan kurang sesuai maka pasien lebih memilih mencari pelayanan kesehatan yang baru (Dinik, 2008). Berdasarkan hasil penelitian, waktu pelayanan di FKTP menunjukkan sebesar $94,44 \%$ sudah sesuai dengan jadwal kerjanya. Artinya peserta sebagian besar sudah puas dengan waktu pelayanan di FKTP nya. Hal ini dikarenakan FKTP telah memiliki aturan tentang standar jadwal pelayanan yang harus diterapkan agar dapat memberikan pelayanan yang prima kepada peserta dan tidak mendapatkan keluhan dari peserta. Hal inilah yang menyebabkan tidak adanya hubungan antara waktu pelayanan dengan keinginan pindah FKTP

\section{Hubungan waktu tunggu dengan keinginan pindah FKTP}

Berdasarkan hasil penelitian menunjukkan waktu tunggu mempunyai hubungan yang signifikan dan menjadi faktor yang paling dominan dengan keinginan perpindahan FKTP. Hasil penelitian ini sejalan dengan penelitian yang dilakukan oleh Bambang (2011) yang menyebutkan waktu tunggu mempunyai hubungan yang kuat dengan kepuasan keluarga pasien dan berdampak pada loyalitas pasien dalam memanfaatkan pelayanan kesehatan. Berdasarkan penelitian (Aisyah, 2015) menyebutkan waktu tunggu yang lama di pelayanan kesehatan ini disebabkan karena jumlah kunjungan pasien yang tinggi, kurangnya petugas di loket pendaftaran, keterbatasan ruangan yang ada, dan juga dikarenakan kurangnya tenaga medis (dokter, bidan, perawat) untuk melayani pasien yang datang. Dimana jika waktu tunggu untuk mendapatkan pelayanan medis cepat maka pasien akan cenderung kembali memanfaatkan faskes tersebut dan sebaliknya jika waktu untuk mendapatkan pelayanan medis terlalu lama, maka pasien cenderung akan memiliki keinginan untuk mencari pelayanan kesehatan yang baru.

\section{Hubungan jarak dengan keinginan pindah FKTP}

Hasil uji analisis juga menunjukkan terdapat hubungan yang signifikan antara jarak ke FKTP dengan keinginan pindah FKTP. Hasil penelitian ini sejalan dengan penelitian yang dilakukan Meylanie (2010) 
yang menyatakan bahwa ada hubungan yang signifikan antara akses ke fasilitas kesehatan dengan pemilihan penolong persalinan. Semakin jauh letak geografis FKTP dari tempat tinggal maka semakin banyak responden yang ingin pindah FKTP dan semakin dekat letak geografis FKTP dari tempat tinggal menyebabkan lebih sedikit yang ingin pindah FKTP. Hal inilah yang membuat jarak merupakan salah satu pertimbangan penting dalam memilih pelayanan kesehatan dan munculnya keinginan pindah FKTP apabila fasilitas kesehatan tingkat pertamanya jauh dari tempat tinggal.

\section{Hubungan pindah domisili dengan Keinginan pindah FKTP}

Hasil uji analisis juga menunjukkan, terdapat hubungan yang signifikan antara pindah domisili dengan keinginan pindah FKTP. Pada saat survei, hal ini disebabkan karena masih banyak peserta JKN Mandiri di Kota Denpasar yang tempat tinggalnya tidak menetap, mereka pindah tempat tinggal dikarenakan pekerjaan, kuliah/sekolah, dan mempunyai tempat tinggal baru. Hal ini yang membuat mereka mempunyai keinginan untuk mendapatkan asuransi pelayanan kesehatan di tempat tinggal yang baru. Berdasarkan penelitian Rahmad (2016) juga menunjukkan pasien yang pernah pindah tempat tinggal cenderung akan memilih pelayanan kesehatan yang dekat dengan tempat tinggal barunya. Hal inilah yang menyebabkan adanya hubungan yang signifikan antara pernah pindah domisili dengan keinginan pindah FKTP pada peserta JKN Mandiri di Kota Denpasar.

\section{SIMPULAN}

Terdapat hubungan antara ketersediaan fasilitas di FKTP, waktu tunggu di FKTP, jarak ke FKTP, pelayanan dokter di FKTP dan pindah domisili dengan keinginan pindah FKTP serta tidak terdapat hubungan antara waktu pelayanan di FKTP dengan keinginan pindah FKTP pada peserta JKN Mandiri di Kota Denpasar

\section{DAFTAR PUSTAKA}

Aisyah. 2015. Pengaruh Waktu tunggu Pasien di Tempat Pendaftaran Pasien Rawat Jalan Terhadap Tingkat Kepuasan Pasien di RSUD DR.R.M Djoelham Binjal Tahun 2016. Akademi Perekam Medik dan Informasi Kesehatan (Apikes) Imelda Meda

Bambang. 2011. Kepuasan Keluarga Pasien Terhadap Waktu Tunggu Pelayanan di Instalasi Rawat Jalan Rumah Sakit Jiwa Propinsi Kalimantan Barat. Tesis. Uiniveritas Gadjah Mada

BPJS Kesehatan Cabang Denpasar. (2016). Laporan Mapping, Kunjungan, Rujuk Kantor Cabang Denpasar Bulan Oktober Tahun 2016. Denpasar.

BPJS Kesehatan Cabang Denpasar. 2014. Alur Kerja BPJS Kantor Cabang Denpasar tahun 2014. Denpasar

Dinik, Retnowati. (2008). Kualitas Pelayanan Kesehatan di Puskesmas Bringin Kabupaten Semarang. Skripsi. Fakultas Ilmu Sosial dan Ilmu Politik. Universitas DiponegoroTesis. Program Studi Kajian Rumah Sakit. Prgram Pasca Sarjana, Fakultas Kesehatan Masyarakat, Universitas Indonesia

Indryani. (2013). Analisis Faktor- faktor yang Berhubungan Dengan Utilisasi 
Pelayanan Rumah Sakit Puri Cinere

Tahun 2013. Fakultas Kedokteran

Islam Negeri Syarif Hidayatullah

Jakarta

Meylani, d.r. (2010). Faktor-Faktor yang Berhubungan dengan Pemilihan Tenaga Penolong Persalinan di Wilayah Kerja Puskesmas Jelbuk Kabupaten Jember Tahun 2010. Skripsi. FKM UI

Hanif, Mufriady Akmal. 2011. Analisis Tingkat Permintaan Pasien terhadap Pelayanan Rawat Jalan di Poliklinik Penyakit Dalam RSUP Dr. M Djamil Padang Tahun 2011. Tesis. Program Studi Kajian Rumah Sakit. Prgram Pasca Sarjana, Fakultas Kesehatan Masyarakat, Universitas Indonesia

Rahmad, Ridwan. (2016). Faktor Yang Berhubungan Dengan Pemilihan Fasilitas Kesehatan Tingkat Pertama Pada Peserta Non Pnerima Bantuan Iuran di Wilayah Kerja Puskesmas Lima Kaum I Kabupaten Tanah Datar Tahun 2016. Diploma thesis, Universitas Andalas

Widiastuti, M. (2015). Program Pascasarjana Universitas Udayana Denpasar 2015. Hubungan Jenis Fasilitas Kesehatan Tingkat Pertama, Status Kepesertaan Dan Karakteristik Sosio Demografis Dengan Tingkat Kepuasan Pasien JKN Di Kota Denpasar 